\title{
Strategi Media Sosial Untuk Pengembangan
}

\section{UMKM}

\author{
Maria Nila Anggia Rini ${ }^{1}$, Muhammad Rifki Shihab ${ }^{2}$ \\ ${ }^{1}$ Informatika, Universitas Kristen Duta Wacana \\ Jl. dr. Wahidin Sudirohusodo no. 5-25, Yogyakarta \\ nila@ti.ukdw.ac.id \\ ${ }^{2}$ Ilmu Komputer, Universitas Indonesia \\ Kampus UI Depok 16424, Jawa Barat \\ shihab@cs.ui.ac.id
}

\begin{abstract}
Social Media is an internet-based application that is currently most widely used by the people of Indonesia. Many cases state that social media not only used for socializing but also used for marketing strategies. But running social media as marketing cannot be done instantly. In practice, people give up easily after doing marketing with social media. The purpose of this paper is to formulate a social media strategy that can be applied to small businesses to expand the marketing area. The process of collecting data is by interview, observation, and literature study where the research steps use the Social Media Strategy Lardi Framework. The object of research in this paper is Caritas Furniture. Caritas furniture represents small businesses that do not use long-term planning in running a business. This research produces social media strategies that can be applied to small businesses so that they can expand the marketing area. With the social media strategy that has been formulated, it is expected that small-scale business actors will get an idea of what needs to be prepared and how to use social media.
\end{abstract}

Intisari- Media Sosial adalah aplikasi berbasis internet yang saat ini paling banyak digunakan oleh masyarakat Indonesia. Banyak kasus yang mengatakan bahwa media sosial tidak hanya digunakan untuk bersosialisasi saja tetapi juga digunakan sebagai strategi pemasaran. Namun dalam menjalankan media sosial sebagai pemasaran tidak dapat dilakukan seperti membalikkan telapak tangan. Pada praktiknya orang mudah menyerah setelah melakukan pemasaran dengan media sosial. Tujuan makalah ini adalah untuk merumuskan strategi media sosial yang dapat diterapkan pada usaha kecil untuk memperluas area pemasaran. Proses pengumpulan data adalah dengan wawancara, observasi, dan studi literatur di mana langkahlangkah penelitian menggunakan Kerangka Kerja Lardi Strategi Media Sosial. Objek penelitian pada makalah ini adalah Mebel Karitas. Mebel karitas mewakili usaha kecil yang tidak menggunakan perencanaan jangaka panjang dalam menjalankan usaha. Penelitian ini menghasilkan strategi media sosial yang dapat diterapkan untuk usaha kecil sehingga dapat memperluas area pemasaran. Dengan strategi media sosial yang telah dirumuskan diharapkan pelaku usaha kecil mendapat gambaran apa saja yang perlu dipersiapkan dalam menggunakan media sosial serta bagaimana cara menggunakan media sosial.

Kata Kunci- Media Sosial, Usaha Kecil, Pemasaran, Strategi, Strategi Media Sosial, Kerangka Kerja Lardi Strategi Media Sosial

\section{Pendahuluan}

\section{A. Latar Belakang Masalah}

Berdasarkan data dari Kementrian Koperasi dan Usaha Kecil dan Menengah dapat dilihat bahwa UMKM (Usaha Mikro, Kecil dan Menengah) memiliki peran besar dalam perekonomian Indonesia. Dari total unit kerja yang ada di Indonesia, 99,9\% adalah UMKM. Tenaga kerja yang mampu diserap sebanyak $97,16 \%$ dari total unit usaha dan berkontribusi terhadap 59,08\% PDB [1].

Buku [2], menyebutkan bahwa UMKM merupakan skala usaha yang sulit berkembang karena tidak mencapai skala usaha yang ekonomis. UMKM sangat rentan terhadap masalah-masalah perekonomian. Seperti yang diungkapkan Kuncoro dalam [2], UMKM memiliki kendala yang dialami. Kendala tersebut berupa tingkat kemampuan, keterampilan, keahlian, manajemen sumber daya manusia, kewirausahaan, pemasaran, dan keuangan. Namun menurut Presiden Indonesia Marketing Association (IMA) Muhammad Awaluddin, faktor pengetahuan (knowledge) menjadi persoalan utama terutama pengetahuan berbisnis dan marketing. Muhammad Awaluddin mengungkapkan bahwa aksesibilitas ke pasar juga menjadi permasalahan mereka [3]

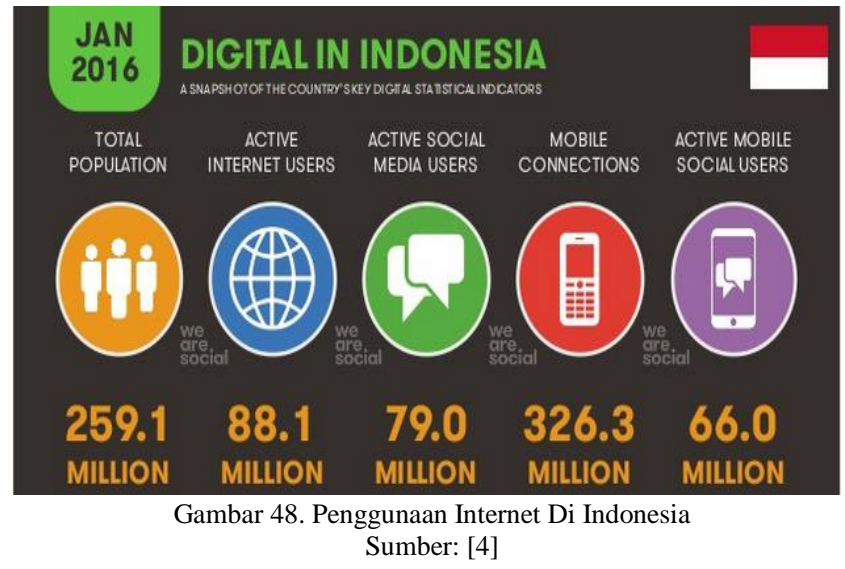

Pada umumnya UMKM belum menggunakan teknologi untuk memperluas daerah pemasaran produk yang 
dihasilkan. Jaringan internet merupakan salah satu teknologi yang dapat dipergunakan untuk memperluas daerah pemasaran, khususnya media sosial. Menurut laporan data pengguna website, mobile, dan media sosial dari seluruh dunia yang diterbitkan oleh We Are Social, Indonesia memiliki 88,1 juta pengguna aktif internet di mana 79 juta pengguna aktif media sosial. Data dapat dilihat pada Gambar 48 yang menggambarkan data penggunaan internet di Indonesia.

Berdasarkan data tersebut, UMKM dapat memanfaatkan media sosial sebagai strategi untuk memperluas daerah pemasaran, terlebih pada pengguna media sosial. Thomas Schenke dalam buku [5], menyebutkan perbedaan mengapa penggunaan media sosial dalam pemasaran memberikan nilai lebih dari pada pemasaran tradisional. Ia juga menyebutkan media sosial memiliki nilai yang lebih, yaitu bersifat personal kemudian pelanggan dapat tersentuh dengan cepat.

Namun saat ini, belum ada strategi media sosial yang dapat langsung digunakan dan diimplementasi pada UMKM. Oleh karena itu, artikel ini menghasilkan strategi yang umum yang dapat dipakai oleh UMKM. Hal ini disebabkan karena artikel dibuat berdasarkan best practice penggunaan media sosial. Strategi yang dihasilkan diharapkan dapat menjadi dasar bagi UMKM dalam penggunaan media sosial untuk mengembangkan bisnis.

\section{B. Rumusan Masalah}

Pada latar belakang sudah disebutkan masalah yang terjadi di UMKM. Permasalahan yang mendasar adalah skala usaha yang sulit berkembang karena tidak mencapai skala usaha yang ekonomis. Selanjutnya ditelusuri akar-akar masalah dengan menggunakan diagram fishbone. Buku [2], menyebutkan beberapa masalah dan tantangan yang dihadapi oleh UMKM di Indonesia. Paling tidak terdapat delapan (8) hambatan yang dihadapi oleh UMKM yang relevan dengan penelitian ini, yaitu:

1. Tingkat keterampilan, keahlian, kemampuan, dan manajemen sumber daya manusia

2. Kelemahan dalam memperoleh peluang pasar dan memperbesar pangsa pasar

3. Kelemahan dalam struktur permodalan dan keterbatasan untuk memperoleh jalur untuk sumbersumber permodalan

4. Keterbatasan jaringan usaha kerja sama antar pengusaha kecil

5. Iklim usaha yang kurang kondusif karena iklim usaha yang mematikan

6. Kurangnya kepercayaan serta kepedulian masyarakat terhadap usaha kecil

7. Persaingan dalam merebut pasar semakin ketat

8. Permasalahan kualitas barang

Peneliti memetakan delapan hambatan UMKM dengan permasalah yang terjadi di lapangan. Berdasarkan hasil analisis terdapat 4 domain masalah yang dinilai dapat menyebabkan skala usaha UMKM sulit berkembang.

Domain-domain tersebut adalah domain Pasar, Keuangan, Pesaing, dan Barang. Domain dan akar-akar masalah tergambar pada Gambar 2.

Peneliti tidak memasukkan permodalan sebagai akar- akar masalah karena saat ini masalah permodalan sudah dipermudah oleh pemerintah melalui Badan Ekonomi Kreatif (Bekraf).

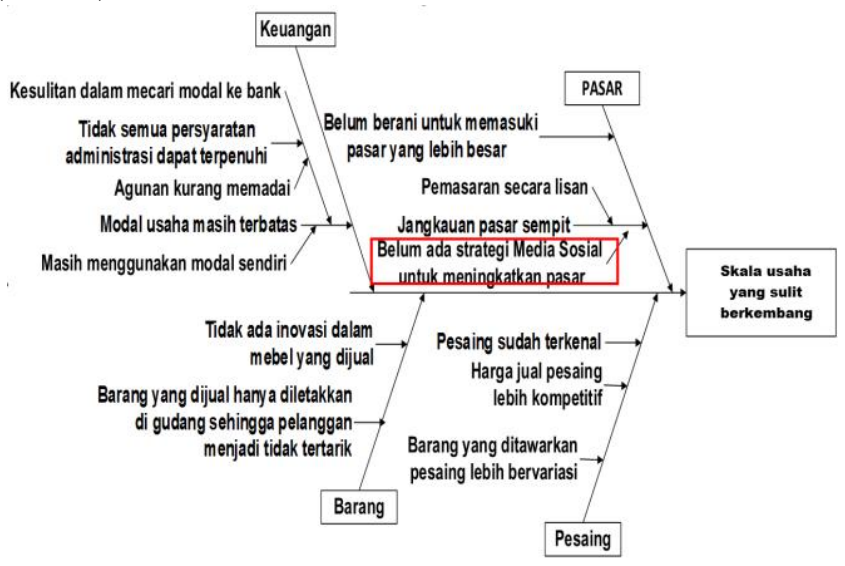

Gambar 49. Diagram Tulang Ikan

Sumber: Hasil Wawancara dan observasi yang telah diolah

Selain permodalan, peneliti juga tidak memasukkan kualitas barang sebagai akar-akar masalah. Hal ini disebabkan karena untuk dapat bersaing maka kualitas barang harus dijaga dengan baik.

Penelitian ini difokuskan pada penggunaan media sosial. Media sosial dapat membantu dalam memperluas pasar pada UMKM. Menurut Thomas Schwenke, terdapat beberapa poin perbedaan mengapa penggunaan media sosial dalam pemasaran memberikan nilai lebih daripada pemasaran tradisional. Perbedaan tersebut dirangkum dalam Tabel I.

TABEL VI

Perbandingan Pemasaran Via Media Sosial dan Tradisional

\begin{tabular}{|c|c|c|}
\hline & Tradisional & Media Sosial \\
\hline $\begin{array}{l}\text { Arah } \\
\text { Komunikasi }\end{array}$ & $\begin{array}{l}\text { Komunikasi satu arah: } \\
\text { Informasi disebar oleh } \\
\text { perusahaan dan pelanggan } \\
\text { hanya mendengar }\end{array}$ & $\begin{array}{l}\text { Komunikasi dua arah: } \\
\text { Perusahaan dan } \\
\text { pelanggan saling berbagi } \\
\text { informasi, berbicara, dan } \\
\text { mendengar }\end{array}$ \\
\hline $\begin{array}{l}\text { Tipe } \\
\text { Pemasaran }\end{array}$ & $\begin{array}{l}\text { Seragam, jelas: } \\
\text { iklan kampanye, layanan } \\
\text { hotline }\end{array}$ & $\begin{array}{l}\text { Membedah, tidak jelas } \\
\text { blog, update status, } \\
\text { tweets, tanggapan } \\
\text { ulasan, jawaban di forum }\end{array}$ \\
\hline $\begin{array}{l}\text { Perencanaan } \\
\text { iklan }\end{array}$ & Persiapan panjang & Spontan \\
\hline $\begin{array}{l}\text { Komunikasi } \\
\text { dengan } \\
\text { pelanggan }\end{array}$ & $\begin{array}{l}\text { Dipertimbangkan dengan } \\
\text { baik dan diskusi: } \\
\text { Komunikasi terjadi hanya } \\
\text { antara pemasok dan } \\
\text { pelanggan. Proses diskusi } \\
\text { rahasia dan orang lain } \\
\text { tidak dapat ikut } \\
\text { didalamnya }\end{array}$ & $\begin{array}{l}\text { Cepat dan langsung } \\
\text { reaksi: } \\
\text { Komunikasi dengan } \\
\text { pelanggan terjadi di } \\
\text { depan umum. Semua } \\
\text { orang dapat melihat dan } \\
\text { ikut ambil bagian dalam } \\
\text { diskusi }\end{array}$ \\
\hline Availability & Dalam jam kerja & Permanen $(24 X 7)$ \\
\hline Scope & $\begin{array}{l}\text { Spesifik: } \\
\text { Mencapai pasar dan } \\
\text { kelompok sasaran tertentu }\end{array}$ & $\begin{array}{l}\text { General: } \\
\text { Tersedia untuk semua } \\
\text { orang dan di mana pun }\end{array}$ \\
\hline Bahasa & $\begin{array}{l}\text { Formal, aman secara } \\
\text { hukum: } \\
\text { bahasa marketing, tidak } \\
\text { menyalahi hukum, } \\
\text { disiapkan dengan matang }\end{array}$ & $\begin{array}{lr}\text { Otentik \& langsung ke } \\
\text { personal: } \\
\text { Tidak } & \text { dipersiapakan } \\
\text { namun } & \text { langsung } \\
\text { ditujukan } & \text { kepada } \\
\text { pelanggan } & \end{array}$ \\
\hline
\end{tabular}


Berdasarkan pemikiran Thomas Schenke pada buku [5], penulis mengambil kesimpulan bahwa dengan media social, pelaku usaha dapat melakukan pemasaran dengan lebih personal dan cepat dalam menyentuh pelanggan.

Dari masalah-masalah yang telah dijabarkan dalam Gambar 49, penulis mengangkat domain Pasar. Domain Pasar merupakan salah satu yang dapat menyebabkan skala usaha sulit berkembang. Penyebab jaringan pasar yang sempit tersebut adalah UMKM belum memanfaatkan media sosial sebagai strategi pemasaran. Seperti yang dikatakan Thomas Schenke, media sosial dapat digunakan untuk melakukan pemasaran.

Akar masalah belum adanya strategi media sosial inilah yang diangkat menjadi dasar dari penelitian ini, yaitu: bagaimana strategi media sosial yang tepat untuk memperluas pasar sehingga skala usaha UMKM dapat berkembang.

\section{KAJIAN PUSTAKA}

\section{A. Landasan Teori}

1) Media Sosial: Media sosial adalah alat komunikasi masa depan, kumpulan alat dan platform berbasis internet yang tak terhitung jumlahnya yang dapat meningkatkan infomasi yang dibagi. Dengan terbentuknya media baru ini membuat pengiriman teks, foto, suara, video, dan informasi semakin mudah dan sering oleh kalangan pengguna internet. Media sosial tidak hanya digunakan oleh pengguna internet untuk sekedar bersosialisasi saja tapi juga melakukan bisnis [6].

Sejalan dengan yang telah diungkapkan pada The Social Media Bible, Safko dan Brake menyatakan bahwa media sosial merupakan kegiatan atau alat yang memungkin masyarakat berkumpul secara online untuk berbagi dan memperkaya informasi [7].

Sedikit berbeda dengan kedua pendapat yang telah diungkapkan sebelumnya, Kaplan dan Haenlein mengatakan bahwa media sosial adalah kelompok aplikasi yang berjalan dalam jaringan internet yang terbentuk pada dasar ideologi dan teknologi web 2.0 yang memungkinkan penciptaan dan pertukaran konten yang dipicu oleh pengguna (User Generated Content) [8].

Sejalan dengan Kaplan dan Haenlein, Chaffey berpendapat bahwa media sosial merupakan salah satu kategori media yang berfokus pada partisipasi dan komunikasi peer-to-peer antara individu dengan situs online yang mampu menyediakan ruang untuk user generated content dan untuk pertukaran pesan dan komentar antara pengguna yang berbeda [9].

Jika Safko dan-Brake lebih menekankan kepada pertukaran infomasi antar pengguna sehingga informasi yang ditampilkan pada situs online menjadi lebih kaya, Kaplan, Haenlein, dan Chaffey mempunyai pendapat bahwa media sosial tidak sekedar tempat untuk berbagi informasi. Mereka berpendapat media sosial merupakan tempat untuk individu menciptakan konten mereka sendiri (user generated content), sehingga para pengguna media sosial menciptakan konten, membagi konten, dan memperkaya konten tersebut.

Menurut buku yang ditulis oleh Chaffey, media sosial dapat dikatakan lebih dari pada sekedar jaringan sosial. Kategori tersebut adalah Social networking, Social knowledge, Social sharing, Social news, Social streaming, dan Social user generated content and community [9].

Dari seluruh pendapat tersebut, media sosial dapat diartikan sebagai suatu sarana berkomunikasi yang berbasis internet yang bertujuan untuk bertukar informasi. Informasi atau konten yang terdapat di media sosial dapat diciptakan oleh pemilik situs ataupun diciptakan oleh pengguna media sosial, kemudian konten tersebut dibagi ke pengguna lain dan diperkaya dengan memberikan komentar, tanggapan, dan ratting. Informasi tersebut dikirimkan dalam bentuk bentuk teks, gambar, video, dan suara.

Media sosial dapat dirumuskan ke dalam 5 (lima) unsur, yaitu: pengguna, jaringan, teknologi, informasi/konten, dan interaksi antar pengguna.

2) Pemasaran: Kothler mendefinisikan pemasaran sebagai suatu proses sosial dan managerial yang membuat individu dan kelompok memperoleh apa yang mereka butuhkan dan inginkan melalui penciptaan dan pertukaran, hubungan timbal balik produk dan nilai dengan orang lain [10].

Terdapat konsep utama pada pemasaran yang dapat digunakan untuk lebih memahami fungsi pemasaran, yaitu Needs, Wants, dan Demands, Target Markets, Positioning, dan Segmentation, Offerings and Brands, Value and Satisfaction, Marketing Channels, Supply Chain, Competition, dan Marketing Environmen.t

3) Strategi: Porter, dalam buku "Introduction to ECommerce", menyebutkan strategi adalah broad-based formula untuk mengetahui bagaimana bisnis akan bersaing, tujuan yang harus dicapai, dan kebijakan apa yang diperlukan untuk mencapai tujuan. Strategi berarti pencarian tindakan yang secara signifikan dapat mengubah posisi perusahaan saat ini dan menentukan masa depan [11].

Sejalan dengan yang disampaikan oleh Porter, dalam buku "Exploring Corporate Strategy" disebutkan bahwa strategi menitikberatkan pada arah jangka panjang suatu organisasi. Strategi dapat dilihat sebagai pencarian langkah strategis yang cocok dengan lingkungan perusahaan. Dapat dilihat pula sebagai cara menciptakan peluang dengan membangun sumber daya dan kompetensi perusahaan [12].

Berdasarkan pendapat para ahli tersebut, strategi dapat dikatakan sebagai langkah jangka panjang yang digunakan untuk mencapai suatu tujuan. Jika dilihat dari sudut pandang perusahaan, tujuan yang ingin diraih adalah meningkatkan kompetensi, menciptakan peluang, dan merubah kondisi perusahaan.

4) Strategi Media Sosial: Menurut Lardi dan Fuchs, strategi media sosial diartikan sebagai langkah-langkah yang didasari pencarian pada seluruh rantai nilai bisnis 
untuk mengidentifikasi di sisi mana saja media sosial dapat berkontribusi untuk mencapai tujuan bisnis. Dari strategi ini menghasilkan visi media sosial untuk perusahaan, kesiapan organisasi untuk mengadopsi media sosial, dan rencana adopsi media sosial yang selaras dengan tujuan bisnis [13].

Media sosial merupakan aplikasi berbasis internet yang memfasilitasi percakapan antar pengguna. Untuk memfasilitasi percakapan tersebut, maka memerlukan langkah untuk melibatkan (engage) pengguna. Menurut Safko dan Brake, terdapat empat (4) cara untuk melibatkan (engage) orang dengan media sosial, yaitu Communication, Collaboration, Education, dan Entertainment [7].

5) Social Capital: Manusia dapat melakukan hal-hal yang tidak dapat mereka lakukan sendiri dengan cara bekerja sama dengan orang lain. Hal tersebut dapat dilakukan jika manusia dapat membangun dan menjaga hubungan dengan sesama. Hubungan terjalin melalui jaringan dan di dalamnya cenderung memiliki kesamaan nilai. Sehingga jaringan dan kesamaan nilai merupakan inti dari konsep modal sosial [14].

Dalam buku Social Capital, Coleman memiliki pandangan sendiri mengenai modal sosial. Menurutnya modal sosial adalah struktur hubungan antar individu yang memungkinkan mereka untuk menciptakan nilai-nilai baru [14].

Masih dalam buku Social Capital, menurut Putnam, modal sosial adalah bagian dari kehidupan yang mendorong partisipan bekerja sama untuk mencapai tujuan [14].

Berdasarkan teori-teori tersebut dapat disimpulkan bahwa modal sosial merupakan hubungan yang terjalin karena jaringan dan kesamaan nilai antara individu, yang memungkinkan terciptanya nilai baru untuk mencapai tujuan tertentu.

6) Hyper-social Organization: Dengan adanya media sosial, koneksi, dan teknologi, membuat manusia menjadi lebih sosial. Media sosial memberikan kemudahan dalam bersosialisasi dengan sesame manusia, bahkan menjadi aktivitas yang paling sering dilakukan. Hal ini yang menjadi dasar teori hyper-social organization muncul [15].

Teori hyper-social organization, merupakan teori yang dipopulerkan oleh Francois Gossieaux dan Ed Moran. Mereka mengungkapkan faktor pembentuk komunitas yang penting dalam perdagangan adalah Defenders of Belief dan Seekers of the Truth. Defenders of Belief adalah membentuk ikatan yang kuat antara konsumen dan pedagang, bagaimana meyakinkan orang lain, dan berbagi kepercayaan. Seekers of the Truth merupakan kegiatan inovatif dalam memecahkan masalah [15].

Francois Gossieaux dan Ed Moran, mengungkapkan bahwa ada perubahan pola pikir terhadap pemasaran akibat kemunculan media sosial. Mereka menyebutnya sebagai empat (4) pilar dari hyper-social, yaitu: From market segmen to tribes, from company-centricity to human centricity, from information channels to knowledge network, dan from process and hierarchy to social messiness [15].

7) Case Study Research: merupakan sebuah strategi penelitian yang melibatkan suatu investigasi empiris dari fakta yang ada pada suatu saat dalam kehidupan nyata dengan menggunakan berbagai metode pengumpulan data. Tujuan penelitian studi kasus adalah untuk menjelaskan bagaimana keberadaan dan mengapa kasus tersebut dapat terjadi [16].

Penelitian studi kasus ini memiliki terdapat tiga tahapan sederhana, yaitu sebagai berikut [16]:

- Menyusun definisi dan rancangan penelitian

- Menyiapkan, mengumpulkan, dan menganalisis data

- Menganalisis dan membuat kesimpulan

\section{B. Penelitian Sebelumnya}

Penelitian dengan judul "Strategic Use of Social Media for Small Business Based on the AIDA Model" yang dilakukan oleh Hassan, Zaleha, Nadzim, dan Shiratuddin. merumuskan strategi media sosial untuk pengusaha bisnis kecil (UKM) dengan menggunakan model AIDA (Attention, Interest, Desire, and Action). Pengambilan data menggunakan focus group discussion dengan 22 (dua puluh dua) pengusaha kecil yang telah menggunakan media sosial sebagai strategi pemasarannya. Penelitian ini menghasilkan rumusan strategi media sosial untuk pengusaha bisnis kecil (UKM) berdasarkan hasil pikiran para pengusaha [17].

Penelitian dengan judul "Facebook Marketing Strategy for Small Business in Malaysia" yang dilakukan oleh Othman, Bidin, dan Hussain mengevaluasi efektifitas penggunaan layanan media sosial sebagai strategi pemasaran, khususnya facebook. Data diambil dengan proses kuantitatif, yaitu dengan membandingkan antara membuat halaman facebook baru dan meningkatkan halaman facebook yang sudah ada dengan menggunakan strategi yang dirumuskan oleh Falkowl dan strategi media sosial dari Maxwell. Delapan puluh delapan mahasiswa dari kelas $E$ Marketing berpartisipasi dalam penelitian ini. Para peneliti berhasil mendapatkan strategi untuk mendapatkan 'Like' dalam facebook. Peneliti tersebut menyimpulkan bahwa peran dari teman di media sosial memegang peranan penting [18].

Penelitian dengan judul "Development of Social Media Strategies in Tourism Destination" yang dilakukan oleh Királ'ová dan Pavlíčeka menunjukkan bahwa strategi yang selaras dengan media sosial dapat membantu organisasi agar mendapat nilai kompetitif. Data diambil menggunakan metode desk research, yaitu semua data diambil dari data sekunder dan berdasarkan teori-teori yang relevan. Dari penelitian didapatkan tujuan dari kampanye dalam media sosial, pemakaian emosi pelanggan dalam media sosial, best practice untuk melakukan strategi media sosial, dan faktor utama yang mendorong kesuksesan dalam pemanfaatan media sosial [19]. 
Penelitian dengan judul "Best practice in the use of social networks marketing strategy as in SMEs" yang dilakukan oleh Vásquez dan Escamilla untuk mengidentifiasi best practice penggunaan jejaring sosial sebagai strategi pemasaran pada usaha mikro [20].

Keempat penelitian tersebut, memiliki tujuan dan cara yang berbeda satu sama lain. Penelitian pertama membuat suatu strategi dengan model AIDA dan mengambil data dari FGD. Dari hasil pikiran orang lewat FGD tersebut, peneliti kemudian merumusakan strategi media sosial yang dapat dipakai oleh para pengusaha kecil.

Berbeda dengan sudut pandang yang dilihat oleh peneliti kedua, peneliti menggunakan observasi dan perbandingan secara langsung terhadap perilaku penggunaan facebook. Dari hasil observasi itu didapat bagaimana strategi dalam upaya mendapatkan perhatian teman atau pengguna facebook terhadapt halaman yang mereka bagikan.

Jika peneliti pertama dan kedua mengolah data yang diambil dari lapangan, penelitian ketiga dan keempat menggunakan data yang telah diolah oleh peneliti lain. Para peneliti mengambil hasil dari jurnal lain kemudian hasil tersebut menjadi best practice untuk strategi media sosial yang digunakan.

Walaupun penelitian diambil dari sudut pandang yang berbeda, semua penelitian tersebut membuat strategi media sosial yang dapat digunakan untuk melakukan pemasaran terhadap perusahaan atau produk. Hasil penelitian tersebut relevan dengan yang dibuat oleh penulis, yaitu bagaimana membangun suatu strategi media sosial

\section{Framework Media Sosial}

1) The ZHAW/Lardi Social Media Strategy Framework The ZHAW/Lardi Social Media Strategy Framework: diciptakan oleh Kamales Lardi dan Rainer Fuchs. Framework ini mengantarkan perusahaan mengerti nilai dari media sosial. Menutur mereka media sosial dapat digunakan dalam kebutuhan bisnis.

Kerangka ini membagi proses pengembangan dan penerapan strategi media sosial menjadi dua fase, yaitu Fase Mengembangkan strategi dan Fase Merencanakan dan Melaksanakan.

Fase 1 mendorong organisasi untuk menggali alasan mengapa mereka harus mengadopsi media sosial sebagai strategi mereka sebelum berlanjut ke dalam tindakan nyata. Fase 2 dibagi menjadi 2 pendekatan, bergantung bagaimana keterlibatan media sosial dilaksanakan pada individu yang menjadi target.

2) AIDAS: adalah pengembangan dari model AIDA. AIDAS merupakan model yang menggambarkan hubungan pelanggan dengan periklanan dan marketing [21]. Pada penelitian sebelumnya menggunakan model AIDA, namun telah ada element baru yang ditambahkan yaitu Satisfaction.

\section{Theoritical Framework}

Berdasarkan kajian teori dan penelitian sebelumnya, maka dapat dirangkum menjadi kerangka teoritis seperti terlihat pada Gambar 3.
Maksud dari kerangka teroritik tersebut adalah organisasi ingin memperluas pasar dari yang tadinya merupakan perusahaan lokal yang memiliki jangkauan yang sempit berubah menjadi perusahaan dengan jangkauan pelanggan yang lebih luas. Perubahan tersebut dilakukan dengan memanfaatkan media sosial. Oleh karena ini memerlukan strategi media sosial yang akan diaplikasikan pada perusahaan. Pengembangan strategi media sosial dilakukan dengan kerangka kerja The ZHAW / Lardi Social Media Strategy Framework.

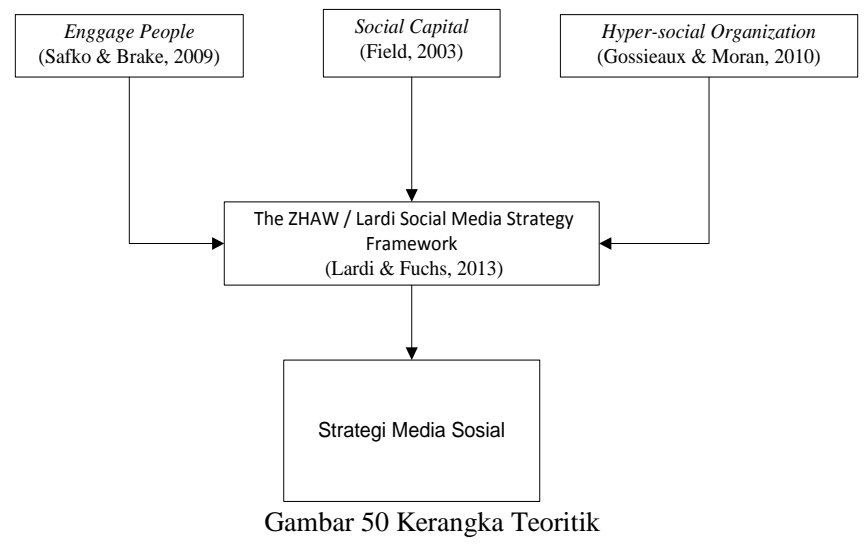

Strategi yang dirancang harus selaras dengan bisnis perusahaan dan lingkungan perusahaan. Pada saat merancang strategi, penulis memerlukan data SWOT perusahaan, tujuan bisnis, dan visi perusahaan ke depan.

Pada studi kasus yang ada, tidak semua strategi media sosial akan berhasil, maka kita bisa mendapatkan lesson learn dan best practice kasus tersebut. Untuk kesusksesan strategi media sosial tidak hanya sekedar menggunakan media sosial untuk pemasaran saja, namun bagaimana perusahaan bisa membuat Modal Sosial (Social Capital) dan Hyper-social organization. Yaitu bagaimana perusahaan dapat menjangkau pelanggan, membentuk suatu grup yang yang bisa memberikan tanggapan kepada perusahaan.

Hal tersebut akan dapat dilakukan jika media sosial dapat digunakan untuk lebih mampu melibatkan pelanggan pada informasi yang ditawarkan perusahaan. Proses untuk melibatkan pelanggan dapat dilakukan dengan Commucation, Collaboration, Education, dan Entertainment.

\section{Metodologi Penelitian}

Penelitian ini menggunakan pendekatan kualitatif yang terdiri atas case study research dan action research. Dalam penelitian ini, peneliti melakukan perumusan terhadap strategi dengan mengambil best practice yang telah dilakukan oleh organisasi dan penelitian lain. Setelah peneliti melakukan perumusan terhadap strategi tersebut selanjutnya pemilik organisasi dan orang-orang yang terkait melakukan validasi terhadap strategi tersebut. Validasi dilakukan dengan melakukan FGD dan diskusi dengan orang-orang terkait.

Studi kasus yang digunakan dalam penelitian ini adalah Mebel karitas sebagai data untuk membuat sebuah strategi 
yang umum dan dapat digunakan oleh UMKM lain.

\begin{tabular}{|c|c|c|c|}
\hline \multicolumn{2}{|r|}{ esearct } & & \\
\hline Proses & Pengumpulan Data Awal & Proses & Identifikasi Masalah \\
\hline Input & Data tact, Data UMKM & Input & Kondisi UMKM saat ini \\
\hline Metode & Observasi, wawancara, Studi interatur & Metode & \begin{tabular}{|l|} 
Studi interatur \\
\end{tabular} \\
\hline \multirow[t]{2}{*}{ Output } & Kondisi penjualan saat ini & Output & Pertanyaan Peneitian \\
\hline & & & $\uparrow$ \\
\hline Proses & Penyusunan Istrumen Penelitian & Proses & Kąian Pustaka \\
\hline Input & Kerangka Teortik & Input & $\begin{array}{l}\text { Pertanyaan penelitian, teor, } \\
\text { penelitian sebelumnya }\end{array}$ \\
\hline Metode & Studi ilteratur & Metode & Studi literatur, $5 \mathrm{C}+2 \mathrm{~S}$ \\
\hline \multirow[t]{2}{*}{ Output } & Poin-poin pertanyaan wawancara & Output & Kerangka Teortik \\
\hline & $\stackrel{\overbrace{}}{\text { Pengujian Pertanyaan Wawancara }}$ & & \\
\hline Inpte & Poin-poin pertanyaen wawancara & & \\
\hline Metode & $\begin{array}{l}\text { Pengujaan apakah pertanyaan sesuail } \\
\text { konteks dan dapat dipahami }\end{array}$ & & \\
\hline Output & $\begin{array}{l}\text { Hasil pengulian, revisi poin pertanyaan } \\
\text { waw ancara }\end{array}$ & & \\
\hline The ZHAII & Vardi Social Media Strategy Framewo & & \\
\hline \multirow{2}{*}{\begin{tabular}{|l|} 
Proses \\
\end{tabular}} & Phase 1 & Proses & Validasi hasil Fase 1 \\
\hline & $\begin{array}{l}\text { Kajaan pustaka, pertanyaan } \\
\text { wawancara }\end{array}$ & Inpte & Dæta hasil phase 1 \\
\hline \multirow{2}{*}{ Metode } & $\begin{array}{l}\text { Wavencald } \\
\text { Studiliteratur, coding. Hermeneutics. }\end{array}$ & Metode & Wawancara \\
\hline & SWOT, lingkungan ekstema & Output & $\begin{array}{l}\text { Masulukan urik menyempumakan } \\
\text { hasil fase } 1\end{array}$ \\
\hline \multirow[t]{2}{*}{ Output } & $\begin{array}{l}\text { Tujuan bisnis, strategi, peluang } \\
\text { media sosial }\end{array}$ & & \\
\hline & & Proses & Phase 2 \\
\hline Proses & \begin{tabular}{|l|} 
Valid asi hasil Fase 2 \\
\end{tabular} & Input & Data hasil phase 1 \\
\hline Inpte & Data hasil phase 1 & Metode & $\begin{array}{l}\text { Studi iteratur, Hemmeneutics. } \\
\text { wamancara }\end{array}$ \\
\hline Metode & $\begin{array}{l}\text { Wawancare } \\
\text { Masukkan urtuk menyempumakan }\end{array}$ & & $\begin{array}{l}\text { Taktik dalam pelaksanaan } \\
\text { pemasaran dengan media sosial }\end{array}$ \\
\hline Output & hasil tase 2 & & pemasaran dengan media sosial \\
\hline \multicolumn{4}{|c|}{ Lation Research } \\
\hline \multirow{2}{*}{$\begin{array}{c}\text { Proses } \\
\text { Input }\end{array}$} & Valid asi hasil strategi & Proses & Penyusunan Strateg \\
\hline & \begin{tabular}{|l|l|} 
Daka strategi dan taktik \\
\end{tabular} & Input & Hasil model framework Lard \\
\hline \multirow{2}{*}{ Metode } & \multirow{2}{*}{\begin{tabular}{|l|}
$\begin{array}{l}\text { Presentasi i kepada pihak yang } \\
\text { berwenang } \\
\text { Pembahasan bersama dengan pihak } \\
\text { bemwenang }\end{array}$ \\
\end{tabular}} & Metode & $\begin{array}{l}\begin{array}{l}\text { Pengumpulan strategi yang dapat di } \\
\text { implementasi }\end{array} \\
\end{array}$ \\
\hline & & Output & $\begin{array}{l}\text { Strategi Pemasaran dengan media } \\
\text { Sosial }\end{array}$ \\
\hline \multirow[t]{5}{*}{ Output } & $\begin{array}{l}\text { Masukkan urtuk men yempurnakan } \\
\text { hasil }\end{array}$ & & \\
\hline & & Proses & Kesimpulan dan Saran \\
\hline & & Input & Hasil anal isa \\
\hline & & Metode & 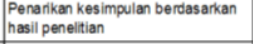 \\
\hline & & Output & Keimpulan dan Saran \\
\hline
\end{tabular}

dalam

Gambar 51, diawali dengan melakukan pengumpulan data awal dengan melakukan observasi dan wawancara pada organisasi. Hasil tersebut digunakan untuk melakukan identifikasi masalah. Identifikasi masalah digunakan untuk menganalisis masalah yang dialami oleh UMKM secara umum. Kemudian permasalah tersebut dipetakan akar permasalahan dengan menggunakan fishbone diagram. Peneliti mengambil akar masalah tersebut kemudian dirumuskan sebuah pertanyaan penelitian.

Pada tahap kajian pusataka, dilakukan pengkajian teori penelitian sebelumnya yang relevan dengan pernyataan penelitian yang telah dirumuskan pada proses identifikasi masalah. Teori, penelitian sebelumnya, dan framework dilakukan proses perbandingan, analisis kekurangan dan kelebihan sehingga didapatkan kerangka teoritik.

Setelah kerangka teoritik ditentukan, selanjutnya dilakukan pengumpulan data. Pertama dilakukan penyusunan instrumen penelitian (poin-poin wawancara yang ditanyakan). Kedua adalah dengan melakukan pengujian pertanyaan wawancara. Ketiga adalah pengumpuan data yang dilakukan dengan identifikasi faktor internal (faktor-faktor yang menjadi kekuatan dan kelemahan organisasi). Pengumpulan data dilakukan dengan melakukan wawancara terhadap pemilik usaha.

Tahap selanjutnya adalah proses identifikasi faktor eksternal yang berupa proses pengumpulan faktor-faktor yang menjadi peluang yang dapat diraih dan ancaman yang dapar menyerang organisasi.

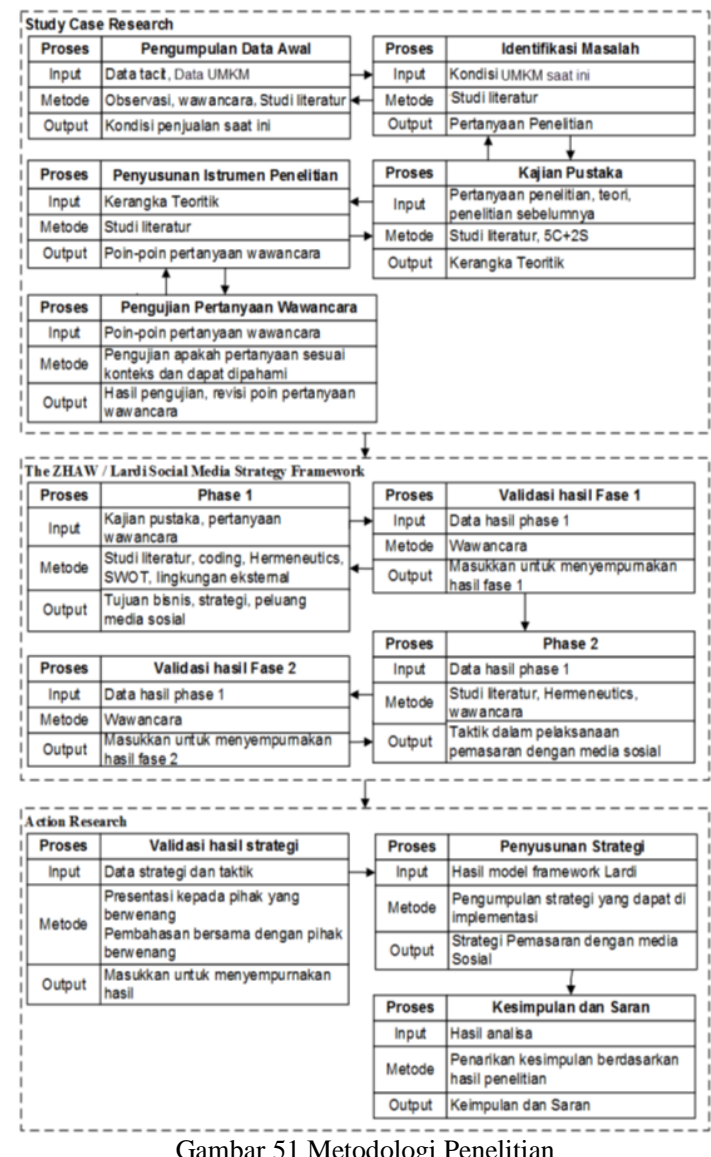

Selanjutnya dilakukan pengolahan data berdasarkan wawancara dan studi literatur. Data-data tersebut menjadi pertimbangan ketika melakukukan penyusunan strategi dengan menggunakan kerangka The ZHAW / Lardi Social Media Strategy.

Setelah strategi terbentuk selanjutnya dilakukan validasi strategi. Rumusan strategi yang telah dibentuk akan divalidasi oleh pihak yang terkait. Dalam hal ini adalah pemilik organisasi serta para pihak-pihak internal organisasi yang mendukung terjadinya usaha.

Proses penyusunan strategi dan validasi dilakukan berulang. Setelah startegi berhasil dirumuskan selanjutnya membuat kesimpulan dan saran. Kesimpulan yang dihasilkan mengambil inti dari hasil penelitian. Saran yang dihasilkan merupakan saran untuk peneliti selanjutnya yang akan mengambil tema yang sama atau yang akan melengkapi hasil dari tema ini.

Penelitian ini menggunakan data primer yang diperoleh melalui metode wawancara dan observasi serta data sekunder yang diperoleh melalui kajian literatur untuk mendapatkan best practice dari berbagai penelitian dan organisasi lain.

\section{ANALISIS}

Penelitian ini menggunakan studi kasus Mebel Karitas. Studi Kasus ini digunakan sebagai data yang menjadi masukan bagi kerangka kerja The ZHAW / Lardi Social Media. Mebel Karitas dipilih sebagai data masukan karena dimaksudkan dapat mewakili UMKM. Mebel Karitas merupakan salah satu contoh UMKM yang masih belum menggunakan teknologi dalam proses bisnisnya. 
Peneliti menjadikan Mebel Karitas sebagai data utama, karena proses di dalam UMKM ini masih manual. Belum ada sistem keuangan, pemasaran, dan visi misi usaha. Mebel Karitas merupakan usaha yang bergerak di bidang industri furniture sejak 17 tahun lalu. Namun dalam memasarkan bisnisnya, Mebel Karitas masih menggunakan cara tradisional (dengan cara mulut ke mulut).

\section{A. Phase 1-Develop Strategy}

\section{Input yang Diperlukan}

Sebelum masuk ke dalam tahap pertama, terlebih dahulu mempersiapkan input yang diperlukan. Input tersebut akan berkontribusi untuk penilaian yang lengkap dan pertimbangan atas keputusan yang akan dibuat. Adapun yang harus dipersiapkan adalah visi-misi usaha, trends assessment, dan customer social media adoption.

Mebel Karitas belum merumuskan misi, nilai-nilai, dan visi perusahaan. Namun dalam wawancara dengan pemilih usaha, peneliti menggarisbawahi bahwa dalam memulai usaha ini pemilik memulai dengan semangat menolong. Awal mula usaha adalah untuk menolong suami untuk meringankan beban keluarga, namun sekarang tujuan utama berubah menjadi menolong masyarakat sekitar untuk mendapatkan penghasilan.

Dari visi yang dibangun tersebut, peneliti mencoba merangkai tujuan strategi untuk meraihnya yaitu dengan pertumbungan keuntungan laba perusahaan, yang diraih dengan pelayanan ke pelanggan. Tujuan strategis ini akan menjadi poin kunci yang akan dicapai dalam penelitian ini adalah bagaimana media sosial dapat berkontribusi untuk menjalankan misi tersebut. Media sosial dapat digunakan untuk membantu dalam mengembangkan kualitas dan pelayanan ke pelanggan.

Media sosial berpotensi dalam memasarkan produk, mengurangi pemasaran melalui pihak ketiga, seperti televisi, radio, dan koran. Erik Qualman dalam buku Socialnomics menyebutkan media sosial merupakan raja baru, yaitu ketika pengguna media sosial merujuk ke produk dan jasa melalui alat media sosial .

Sebagai contohnya Pelanggan tidak lagi berlanggan koran mahal untuk mendapatkan berita, namun mendapatkan berita secara gratis yang lebih relevan dan tepat waktu melalui media sosial. Sehingga dapat dikatakan berita yang menemukan pelanggan [22].

Jane the Blogger mengungkapkan bahwa website atau blog miliknya mendapatkan traffic dari berbagai link yang langsung menuju ceritanya. Hal ini tidak hanya disebabkan oleh pengguna media sosial yang social melakukan reposting, re-tweets, atau linking ke cerita milikinya. Namun Jane mendapatkan traffic dari mesin pencarian. Dengan adanya pengguna media sosial yang merujuk pada suatu website maka akan meningkatkan peringkat pencarian dalam mesin pencarian [22].

Pelanggan dapat membahas berita, produk, dan jasa yang ada dengan orang lain dengan lebih mudah. Pelanggan mendapatkan informasi suatu produk berdasarkan diskusi dengan rekan dalam media sosial hanya dengan alat mobile yang dapat dilakukan dari rumah. Dengan diskusi dan membaca review yang positif secara langsung dapat menyakinkan pelanggan untuk membeli suatu barang [22].

Penjabaran tersebut juga diungkapkan oleh Dave Evans dalam buku "Social Media Marketing The Next Generation of Business Engagement" bahwa dalam saat ini media sosial menjadi bagian dari hampir seluruh pembelian barang. Pembeli beralih untuk mendapatkan dari informasi dari pembeli yang lain untuk membuat keputusan yang tepat. Dave menggambarkan proses dalam pembuatan keputusan tersebut dengan sebuah perulangan. Karena setelah pembeli telah membuat keputusan, maka pembeli tersebut akan aktif dalam media sosial bukan untuk mencari informasi, namun justru untuk memberikan informasi dan pengalaman yang telah pembeli rasakan. Sehingga dapat dikatakan bahwa hasil dari diskusi yang dilakukan dapat mempengaruhi keputusan seseorang untuk membeli produk [23].

Selain itu media sosial juga digunakan untuk mendengarkan dan menerima masukan dari pelanggan. Untuk contohnya pada http://www.gantibaju.com/ mereka menggunakan website untuk mengumpulkan pelanggan dalam suatu forum. Situs ini membuat kompetisi untuk mendesain kaos, kemudian pemenang akan dinilai berdasarkan vote dari pelanggan yang lain. Pengguna media sosial menjadi aktif dalam kegiatan bisnis yang dilakukan oleh pelaku usaha.

Media sosial telah banyak digunakan pengusaha untuk memasarkan produk dan jasa mereka. Di Yogyakarta sendiri pemilik usaha mebel telah menggunakan media sosial sebagai salah satu alat untuk memasarkan produk.

Penulis membandingkan pemanfaatan media sosial yang digunakan oleh usaha mebel lain, yaitu Alam Jati Furniture, Ajeg Mebel Jogja, dan Asram Furniture. Berdasarkan ketiga usaha tersebut penulis dapat menyimpulkan bagaimana penggunaan media sosial dalam bisnis mereka, yaitu:

- Brand Awareness

- Pemasaran Produk

- Meningkatkan lalu lintas ke website pribadi

- Meningkatkan peringkat pada mesin pencarian

- Berpartisipasi dalam online marketplace

\section{Menentukan objectives and readiness}

Strategi harus selaras dengan kondisi yang terjadi dalam perusahaan. Oleh karena itu, peneliti melakukan observasi terhadap kondisi internal dan eksternal usaha.

Pertama peneliti menentukan tujuan bisnis terlebih dahulu. Tujuan bisnis dapat diartikan sebagai tujuan strategis dari perusahaan untuk bisnis yang khusus atau mengidentifikasi bisnis pada saat terdapat tantangan yang harus dihadapi oleh perusahaan.

Berdasarkan hasil perumusan masalah, permasalahan yang dihadapi adalah penjualan dan perbaikan mebel tidak mencapai target. Pemilik berusaha menaikkan penjulan dengan cara memperluas daerah pemasaran. Untuk mencapai tujuan tersebut pemilik ingin menggunakan 
internet dan media sosial sebagai jembatan untuk dapat memperluas daerah pemasaran.

Tujuan yang ingin diraih adalah meningkatnya keuntungan laba perusahaan. Untuk mendefiniskan tujuan bisnis yang akan dijalankan penulis melakukan beberapa tahapan hingga sampai akhirnya diperoleh rumusan tujuan bisnis.

- Studi Literatur, tujuan bisnis dirumuskan dengan dasar model AIDAS.

- Konstruksi rumusan tujuan bisnis oleh penulis, mengambil best practice dari teori-teori yang lain.

- Validasi rumusan tujuan bisnis oleh pemilik organsiasi Setelah dilakukan tahap-tahap tersebut, tujuan bisnis yang digunakan dalam sepanjang penelitian ini adalah:

- Membangun kesadaran calon pelanggan terhadap perusahaan dan produk yang ditawarkan

- Menarik perhatian calon pelanggan dan calon pelanggan terhadap produk

- Meraih kepercayaan para calon pelanggan

- Membangun hubungan dengan pelanggan melalui media sosial

- Responsif terhadap permintaan terhadap produk.

- Follow-up pelanggan setelah melakukan pembelian barang dan jasa.

Penulis mengukur kematangan penggunaan media sosial dengan tools yang dibuat oleh Lardi. Tools dapat diaskes pada http://www.lardipartner.com/\#!socialmedia-maturity-assessment/cws3. Dalam tools ini, peneliti menjawab pertanyaan berdasarkan hasil wawancara dengan pemilik usaha. Kategori yang diperoleh oleh Mebel Karitas dalam Lardi's Social Media Maturity Assassement adalah level Aware.

Level Aware berarti pemilik telah menyadari adanya media sosial namun tidak dapat mengkaitkan dengan bisnis. Karena usaha ini berada pada level awal, dalam menyusun strategi media sosial yang dapat dilakukan tanpa membutuhkan resource yang besar.

Strategi dirumuskan dengan memberikan batasan media sosial yang digunakan untuk memenuhi tujuan bisnis. Penggunaan media sosial difokuskan pada area bisnis yang spesifik. Hal tersebut dimaksudkan agar strategi yang dihasilkan dapat memenuhi tujuan bisnis.

Pertama, berdasarkan pertanyaan penelitian maka strategi media sosial ini berfokus untuk pemasaran. Sehingga media sosial digunakan sebagai media untuk memasarkan produk yang akan berfokus solusi eksternal pada media sosial.

Kedua, target audiens yang ingin diraih dalam penelitian ini adalah pengguna media sosial (baik pemula maupun ahli) dan pengguna yang sudah bekerja.

Ketiga, dalam membangun strategi untuk media sosial terdapat kendala yang harus diperhatikan, agar strategi media sosial yang dibangun dapat mencapai hasil yang diinginkan oleh perusahaan. Adapun kendala yang dihadapi adalah:

- Salah satu kegunaan media sosial adalah untuk generate traffic ke website perusahaan. Maka untuk dapat meraih kepercayaan calon pelanggan, Mebel Karitas membuat website perusahaan.
- Perhatikan bagaimana cara pengiriman dan pembayaran barang.

- Dengan adanya memasarkan produk dengan media sosial maka memerlukan orang yang bertanggung jawab dalam adopsi medial sosial. Sebagai contoh siapa yang membalas pesan dari pengguna media sosial.

Keempat, karena transaksi elektronik dilindungi oleh hukum, maka pemakaian media sosial hendaknya memberikan informasi produk dan perusahaan dengan jelas. Baik dengan menggunakan bahasa yang jelas dan tidak ambigu maupun memberikan gambaran produk yang sesuai dengan kenyataan.

\section{Mengidentifikasi inisiatif dan prioritas}

Tujuan-tujuan bisnis yang telah dirumuskan menjadi dasar dari pembentukan business drivers, peluang media sosial dan strategi. Tahap-tahap dalam perumusan tersebut adalah:

- Studi Literatur, untuk mendapatkan best practice

- Konstruksi rumusan tujuan bisnis oleh penulis

- Setelah mendapatkan business drivers, peluang media sosial dan strategi selanjutnya dilakukan pemetaan business drivers, peluang media sosial dan strategi terhadap tujuan bisnis.

- Validasi rumusan strategi oleh pemilik organsiasi

Perumusan business drivers akan menggunakan 7 business drivers dalam media sosial yang dikemukakan oleh Jason Falls [24].

- Enhance branding and awareness

- Protect brand reputation

- Enhance public relations

- Build community

- Enhance customer service

- Facilitate research and development

- Drive leads and sales

Dari tiap tujuan bisnis selanjutnya ditentukan peluang media sosial sehingga tujuan bisnis dapat tercapai. Peluang bisnis disusun berdasarkan data trend assessment yang telah dijelaskan pada Phase 1. Peluang-peluang bisnis yang didapatkan dari media sosial dan berdasarkan manfaat media sosial yang dikemukakan oleh Jason Falls dalam buku [24]. Adapun peluang media sosial yang digunakan dalam penelitian ini adalah sebagai berikut:

- Meningkatkan kesadaran pengguna media sosial akan perusahaan dan produk yang ditawarkan melalui media sosial.

- Membuat jalur marketing yang efektif, yaitu word-ofmouth marketing. Di mana tiap pengguna media sosial merujuk dan mengomentari suatu produk kemudian membuat pengguna lain tertarik.

- Meningkatkan peringkat pencarian terhadap perusahaan dan produk pada mesin pencarian.

- Meningkatkan peringkat pada mesin pencarian dengan kata kunci yang ditargetkan.

- Menghasilkan traffic ke website perusahaan melalui tautan media sosial dan mesin pencarian.

- Berkomunikasi dan terlibat langsung dengan pelanggan dan calon pelanggan. 
- Membangun dan memelihara hubungan secara langsung antara pelanggan dan perusahaan

- Mengamati percakapan yang terjadi di media sosial yang berkaitan dengan perusahaan.

- Memperluas jangkauan pengiriman pesan mengenai perusahaan dan produk yang ditawarkan.

- Meningkatkan jumlah pelanggan yang loyal yang membela perusahaan dari respon negatif.

- Meningkatkan komentar positif dan mengurangi komentar negatif.

- Meningkatkan kepuasan pelanggan karena pelanggan merasa diperhatikan oleh perusahaan.

- Menghasilkan ide-ide baru untuk meningkatkan kenyamanan pada produk, membuat produk baru, dan melihat produk yang sedang diminati oleh pelanggan.

- Meningkatkan kemungkinan pelanggan membeli produk dari perusahaan.

Pada penelitian ini mengambil fokus utama pada solusi external pada media sosial. Maka tipe peluang yang akan dikaji dalam fase kedua adalah pada tahap Business 2.0 (External Company Focus).

Dari keenam tujuan bisnis perlu dilakukan prioritas. Penentuan prioritas dilakukan dengan kriteria anggaran, ketersediaan sumber daya, dan dampak terhadap bisnis.

Tujuan bisnis ditentukan berdasarkan teori penjualan AIDAS, yang telah melewati langkah-langkah berikut: attention, interest, desire, action, dan satisfaction. Berdasarkan hal tersebut, maka tujuan bisnis yang telah ditentukan memiliki keterkaitan agar tujuan strategis dapat tercapai. Jadi dapat dikatakan bahwa setiap tujuan bisnis tersebut merupakan hal yang harus dilakukan.

Menurut Lardi, langkah terbaik dalam penerapan media sosial adalah dengan mengambil pendekatan secara bertahap. Oleh karena itu Mebel Karitas, penerapan strategi media sosial dibagi menjadi dua (2) tahap.

Pertama adalah Mebel Karitas memperoleh perhatian dan minat pelanggan dan calon pelanggan. Kedua adalah pelayanan untuk meraih hati pelanggan untuk membeli, bagaimana cara pembelian, dan perlakukan kepada pelanggan setelah membeli barang. Pendekatan bertahap tersebut dilakukan agar Mebel Karitas mendapatkan pengalaman dalam menggunakan teknologi, khususnya media sosial.

Untuk setiap prioritas, dipetakan manfaat terhadap tujuan strategis. Manfaat tersebut dipecah menjadi key metrics untuk mengukur dan mengikuti aktifitas media sosial secara terus menerus [13].

Terdapat aspek-aspek yang harus dipertimbangkan oleh pemilik usaha dalam adopsi media sosial. Aspek penting bagi pemilik adalah:

- People, target pasar adalah pengguna dengan usia lebih dari 25 tahun

- Technology, dalam membentuk komunitas, tidak lepas dari teknologi lain (website, email)

- Risks, media sosial terdapat potensi risiko yang dapat terjadi. Resiko yang mungkin terjadi pencurian ide, kemanan data pelanggan, dan reputasi perusahaan jika ada komentar negatif.

Pada lampiran dirangkum pemetaan dari tujuan bisnis sampai dengan metrics untuk mengukur keberhasilan suatu tujuan bisnis.

\section{B. Phase 2 - Plan and Delivery}

Media Sosial telah menyebabkan banyak perubahan dalam sikap dan perilaku orang-orang yang telah digunakan untuk mengontrol massa. Misalnya, pada tahun 2011 media sosial digunakan sebagai alat pengorganisasian massa untuk mengkoordinasikan dan memungkinkan demonstrasi di Mesir. Media sosial memainkan peran penting dalam mempercepat hasilnya karena jumlah besar orang sudah aktif menggunakan saluran ini [13].

Pada fase pertama telah dirumuskan tujuan bisnis, business drivers, peluang media sosial, dan pengukuran keberhasilan pada masing-masing tujuan bisnis. Pada fase kedua ini dilakukan pemetaan terhadap taktik yang akan digunakan di lapangan pada saat media sosial diluncurkan. Proses pembentukan taktik pada fase 2 ini dilakukan dengan tahap-tahap sebagai berikut:

- Studi Literatur, mendapatkan best practice yang telah digunakan pada perusahan lain.

- Konstruksi rumusan tujuan bisnis, berdasarkan best practice perlu disesuaikan dengan tujuan bisnis

- Validasi rumusan taktik oleh pemilik organisasi

- Validasi seluruh strategi, validasi dilakukan oleh sembilan (9) orang yang merupakan pemilik, kerabat dan rekan kerja yang secara langsung dan tidak langsung berpengaruh terhadap organisasi.

Fase ini terdapat empat area fokus, yang menargetkan pada kepentingan eksternal yang memiliki fungsi bisnis yang berbeda. Berdasarkan hasil yang diperoleh dari fase pertama, maka area fokus perusahaan adalah brand awareness dan relationship management.

Setelah area fokus ditentukan maka selanjutnya adalah menentukan taktik yang harus dijalankan. Taktik digunakan untuk memenuhi tujuan bisnis yang telah ditentukan pada fase pertama.

Pada penelitian ini telah dilakukan pemetaan tujuan bisnis dari fase pertama dan kedua maka didapatlah strategi dan taktik yang dapat digunakan untuk membangun pemasaran produk melalui media sosial. Seluruh tujuan bisnis, business driver, strategi, dan taktik yang telah dirumuskan dirangkum dalam lampiran.

\section{KESIMPULAN}

Pada penelitian ini telah dirumuskan pertanyaan penelitian "Bagaimana strategi media sosial yang tepat untuk memperluas pasar sehingga skala usaha UMKM dapat berkembang?" dengan tujuan untuk membuat strategi untuk pemasaran melalui media sosial. Hasil analisis telah berhasil menjawab pertanyaan penelitian tersebut dengan menerapkan kerangka teoritis, metodologi penelitian, dan kondisi perusahaan yang masing-masing telah dijabarkan.

Penelitian ini telah menghasilkan strategi bagi para pelaku UMKM yang memiliki permasalahan yang sama dengan tempat studi kasus. Strategi ini dapat digunakan oleh UMKM sebagai dasar mereka untuk menjalankan pemasaran dengan media sosial. Adapun hasil strategi dijabarkan dalam Lampiran. Terdapat enam tujuan bisnis yang dapat digunakan sebagai awal tujuan adaptasi media sosial. Pelaku UMKM diharapkan tahu mengenai arah dan tujuan 
penggunaan media sosial. Selanjutnya dari tujuan tersebut, dijabarkan lagi bagaimana mencapai tujuan tersebut dan bagaimana pengukuran apakah tujuan sudah terlaksana dengan baik.

Hasil penelitian ini berupa strategi yang dijabarkan dalam Lampiran. Strategi ini dibangun berdasarkan studi kasus. Untuk penelitian selanjutnya dapat dilakukan penelitian mengenai implementasi strategi ini pada UMKM. Penelitian dapat dilakukan dengan membandingan hasil implementasi strategi dan alasan mengapa strategi yang dibuat dalam artikel ini dapat berjalan atau tidak.

Pada artikel ini diungkapkan juga, bahwa selain menggunakan media sosial, UMKM harus membuat website UMKM. Hal ini dimaksudkan agar pelanggan bias lebih percaya pada UMKM. Dari hal tersebut dapat dilakukan penelitian untuk perancangan aplikasi website UMKM yang sesuai dengan kondisi UMKM di lapangan.

\section{UCAPAN TERIMA KASIH}

Terima kasih disampaikan kepada UMKM Mebel Karitas yang telah bersedia menjadi studi kasus pada penelitian ini sebagai data penelitian.

\section{Daftar Pustaka}

[1] Kementerian Koperasi dan UKM , "Kementerian Koperasi dan UKM," 2012. [Online]. Available:

http://www.depkop.go.id/index.php?option=com_phocadownload \&view=category\&id=109: data-umkm-2012\&Itemid=93 . [Accessed 22 April 2015].

[2] C. Frisdiantara and I. Mukhklis, Ekonomi Pembangunan: Sebuah Kajian Teoretis dan Empiris, Malang: Lembaga Penerbitan Kanjuhuran Malang, 2016

[3] "Marketeers," Marketeers, 2 Agustus 2015. [Online]. Available: http://marketeers.com/masalah-utama-ukm-indonesia-ini-kataketua-ima/. [Accessed 5 November 2018].

[4] We Are Social, "We Are Social," Januari 2016. [Online] Available: http://wearesocial.sg/blog/2016/01/digital-2016/. [Accessed 1 Februari 2016].

[5] T. Schwenke, Social Media Marketing \& Recht, Köln: O’Reilly Verlag GmbH \& Co. KG, 2012.

[6] Social Media Defined, "Social Media Defined," 14 Juni 2014 [Online]. Available: http://www.socialmediadefined.com/what-issocial-media/. [Accessed 15 April 2015].

[7] L. Safko and D. K. Brake, The Social Media Bible, Hoboken, New Jersey: John Wiley \& Sons, Inc., 2009.

[8] A. M. Kaplan and M. Haenlein, "Business Horizons, Volume 53, Issue 1," Users of the world, unite! The challenges and opportunities of Social Media, p. 59-68, 2010.

[9] D. Chaffey, E-Businessand E-Commerce Management Strategy, Implementation and Practice, England: Pearson Education Limited, 2011.

[10] P. Kotller, Marketing Management, Upper Saddle River,New Jersey: Pearson Education, Inc., 2009.

[11] E. Turban and D. King, Introduction to E-Commerce, Upper Saddle River, New Jersey: Pearson education, 2003.
[12] G. Johnson, K. Scholes and R. Whittington, Exploring Corporate Strategy, Edinburgh Gate, England: Pearson Education Limited, 2005.

[13] K. Lardi and R. Fuchs, Social Media Strategy, Zürich: Die Deutsche Nationalbibliothek, 2013.

[14] J. Field, Social Capital, New Fetter Lane, London: Routledge, 2003.

[15] F. Gossieaux and E. Moran, Hyper-social Organization: Eclipse Your Competition by Leveraging Social Media, United States: The McGraw-Hill Companies, Inc, 2010.

[16] R. K. Yin, Case Study Research: Design and Methods, 4th Edition, California: Sage Publications, 2009.

[17] S. Hassan, S. Z. A. Nadzim and N. Shiratuddin, "Strategic Use of Social Media for Small Business Based on the AIDA Model," Procedia - Social and Behavioral Sciences, 2014.

[18] I. H. Othman, D. A. Bidin and H. Hussain, "Facebook Marketing Strategy for Small Business in Malaysia," Informatics and Creative Multimedia, 2013.

[19] A. Királ'ová and A. Pavlíčeka, "Development of Social Media Strategies in Tourism Destination," Procedia - Social and Behavioral Sciences, 2014.

[20] G. A. N. Vásquez and E. M. Escamilla, "Best practice in the use of social networks marketing strategy as in SMEs," Procedia - Social and Behavioral Sciences 148, p. 533 - 542, 2014.

[21] Fat Bit, "Fat Bit," [Online]. Available: http://www.fatbit.com/uxservices/conversion-rate-optimization.html. [Accessed 22 April 2015].

[22] E. Qualman, Socialnomics : How Social Media Transforms The Way We Live And Do Business, New Jersey: John Wiley \& Sons, Inc., 2009.

[23] D. Evans and J. McKee, Social Media Marketing The Next Generation of Business Engagement, Indiana: Wiley Publishing, Inc., 2010.

[24] J. Falls and E. Deckers, No Bullshit Social Media, United States of America: Pearson Education, Inc., 2012.

[25] wer, "werwer," wer, vol. wer, no. wer, p. wer, wer.

[26] C. Supriadi, "Kelebihan dan Kekurangan Berbagai Media Periklanan," 22 May 2013. [Online]. Available: http://www.marketing.co.id/kelebihan-dan-kekurangan-berbagaimedia-periklanan/. [Accessed 12 June 2016].

[27] qweqweqwe, "qwe," [Online]. Available: qwe.

[28] K. Lardi, "http://www.lardipartner.com/," [Online]. Available: http://www.lardipartner.com/\#!social-media-maturityassessment/cws3. [Accessed 20 April 2016]. 
Lampiran

\begin{tabular}{|c|c|c|c|c|c|c|c|}
\hline $\begin{array}{l}N \\
o\end{array}$ & $\begin{array}{c}\text { Business } \\
\text { Goals }\end{array}$ & $\begin{array}{c}\text { Business } \\
\text { Drivers }\end{array}$ & $\begin{array}{l}\text { Social Media } \\
\text { Opportunities }\end{array}$ & $\begin{array}{l}\text { Opportun } \\
\text { ity Type }\end{array}$ & Social Media Tactics & $\begin{array}{l}\text { Strategic } \\
\text { measure }\end{array}$ & $\begin{array}{c}\text { Tactic } \\
\text { Measurement }\end{array}$ \\
\hline 1 & $\begin{array}{l}\text { Membang } \\
\text { un } \\
\text { kesadaran } \\
\text { calon } \\
\text { pelanggan } \\
\text { terhadap } \\
\text { perusahaa } \\
\text { n dan } \\
\text { produk } \\
\text { yang } \\
\text { ditawarka } \\
\text { n }\end{array}$ & $\begin{array}{l}\text { Enhance } \\
\text { branding } \\
\text { and } \\
\text { awareness }\end{array}$ & $\begin{array}{lr}\text { - } \begin{array}{l}\text { Meningkatkan } \\
\text { kesadaran }\end{array} \\
\text { pengguna media } \\
\text { sosial rana } \\
\text { perusahaan dan } \\
\text { produk yang } \\
\text { ditawarkan melalui } \\
\text { media sosial. } \\
\text { - Memperluas } \\
\text { jangkauan } \\
\text { pengiriman pesan } \\
\text { mengenai } \\
\text { perusahaan dan } \\
\text { produk } \\
\text { ditawarkan. yang } \\
\text { - Menghasilkan } \\
\text { traffic ke website } \\
\text { perusahaan melalui } \\
\text { tautan media sosial } \\
\text { dan } \\
\text { pencarian. }\end{array}$ & $\begin{array}{l}\text { Business } \\
2.0\end{array}$ & $\begin{array}{l}\text { - membuat website } \\
\text { perusahaan } \\
\text { - mengiklankan } \\
\text { media sosial atau } \\
\text { keikutsertaan dalam } \\
\text { marketplace } \\
\text { - menjadi } \\
\text { teman/follower } \\
\text { account } \\
\text { lain/perusahaan lain } \\
\text { sehingga nantinya } \\
\text { bisa } \\
\text { mengenal saling } \\
\text { - meningkatkan } \\
\text { like/comment } \\
\text { sehingga peringkat } \\
\text { di mesin pencari } \\
\text { juga meningat } \\
\text { - menggunakan juga } \\
\text { marketing secara } \\
\text { tradisional seperti di } \\
\text { koran link } \\
\text { - menciptakan link } \\
\text { dari media sosial ke } \\
\text { website untuk } \\
\text { memperoleh } \\
\text { trafic/visitor } \\
\end{array}$ & $\begin{array}{l}\text { - Ratting pada } \\
\text { mesin } \\
\text { pencarian } \\
\text { - Meningkatnya } \\
\text { calon } \\
\text { pelanggan }\end{array}$ & $\begin{array}{l}\text { - Jumlah } \\
\text { komentar, like, } \\
\text { dan bookmark } \\
\text { meningkat } \\
\text { - Jumlah } \\
\text { pelanggan yang } \\
\text { menghubungi } \\
\text { bertambah } \\
\text { - Meningkatnya } \\
\text { jumlah mention } \\
\text { untuk } \\
\text { membanding- } \\
\text { kan produk. }\end{array}$ \\
\hline 2 & $\begin{array}{l}\text { Menarik } \\
\text { perhatian } \\
\text { calon } \\
\text { pelanggan } \\
\text { dan calon } \\
\text { pelanggan } \\
\text { terhadap } \\
\text { produk. }\end{array}$ & $\begin{array}{l}\text { Protect } \\
\text { brand } \\
\text { reputation }\end{array}$ & $\begin{array}{ll}\text { - } & \text { Meningkatkan } \\
\text { peringkat pada } \\
\text { mesin pencarian } \\
\text { dengan kata } \\
\text { kunci yang } \\
\text { ditargetkan. } \\
\text { Menghasilkan } \\
\text { traffic ke website } \\
\text { perusahaan } \\
\text { melalui tautan } \\
\text { media sosial dan } \\
\text { mesin pencarian. }\end{array}$ & $\begin{array}{l}\text { Business } \\
2.0\end{array}$ & $\begin{array}{l}\text { - menggunakan kata } \\
\text { kunci/ tag dengan } \\
\text { benar yang dapat } \\
\text { mengundang suatu } \\
\text { kontroversi } \\
\text { - menciptakan } \\
\text { kontroversi } \\
\text { sehingga orang } \\
\text { akan } \\
\text { membicarakannya } \\
\text { - berikan informasi } \\
\text { produk yang terbaru } \\
\text { secara berkala agar } \\
\text { tidak out of date } \\
\end{array}$ & - Nilai sentiment & $\begin{array}{l}\text { - Meningkatnya } \\
\text { komentar } \\
\text { positif yang ada } \\
\text { di media sosial. }\end{array}$ \\
\hline 3 & $\begin{array}{l}\text { Meraih } \\
\text { kepercaya } \\
\text { an para } \\
\text { calon } \\
\text { pelanggan. }\end{array}$ & $\begin{array}{l}\text { Enhance } \\
\text { public } \\
\text { relations }\end{array}$ & 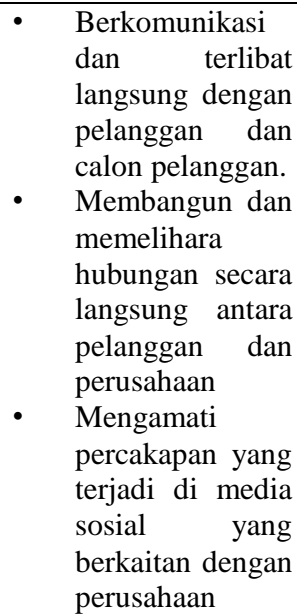 & $\begin{array}{l}\text { Business } \\
2.0\end{array}$ & $\begin{array}{l}\text { - memberikan } \\
\text { informasi yang } \\
\text { tepat mengenai } \\
\text { perusahaan : } \\
\text { alamat, email, no } \\
\text { telp, account media } \\
\text { sosial } \\
\text { - memberikan } \\
\text { informasi yang jelas } \\
\text { mengenai produk } \\
\text { yang ditawarkan : } \\
\text { harga, ukuran, foto } \\
\text { barang aktif berpartisipasi } \\
\text { dan menjawab } \\
\text { feedback pelanggan }\end{array}$ & $\begin{array}{l}- \text { Keterlibatan } \\
\text { pelanggan } \\
\cdot \text { Nilai sentiment }\end{array}$ & $\begin{array}{l}\text { - Meningkatnya } \\
\text { komentar } \\
\text { positif yang ada } \\
\text { di media sosial. } \\
\text { - Meningkatnya } \\
\text { komentar } \\
\text { positif yang } \\
\text { menjawab } \\
\text { komentar } \\
\text { negatif } \\
\text { pelanggan }\end{array}$ \\
\hline
\end{tabular}




\begin{tabular}{|c|c|c|c|c|c|c|c|}
\hline $\begin{array}{l}N \\
o\end{array}$ & $\begin{array}{l}\text { Business } \\
\text { Goals }\end{array}$ & $\begin{array}{l}\text { Business } \\
\text { Drivers }\end{array}$ & $\begin{array}{l}\text { Social Media } \\
\text { Opportunities }\end{array}$ & $\begin{array}{l}\text { Opportun } \\
\text { ity Type }\end{array}$ & Social Media Tactics & $\begin{array}{c}\text { Strategic } \\
\text { measure }\end{array}$ & $\begin{array}{c}\text { Tactic } \\
\text { Measurement } \\
\end{array}$ \\
\hline 4 & $\begin{array}{l}\text { Membang } \\
\text { un } \\
\text { hubungan } \\
\text { dengan } \\
\text { pelanggan } \\
\text { melalui } \\
\text { media } \\
\text { sosial }\end{array}$ & $\begin{array}{l}\text { Build } \\
\text { community }\end{array}$ & 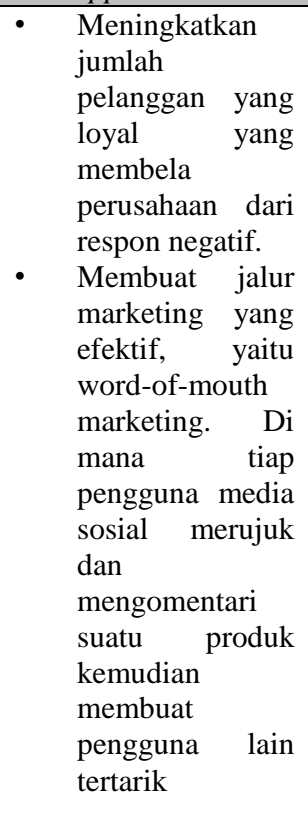 & $\begin{array}{l}\text { Business } \\
2.0\end{array}$ & $\begin{array}{lr}\text { - jika } & \text { terdapat } \\
\text { sentimen negatif, } \\
\text { berikan komentar } \\
\text { agar pelanggan } \\
\text { menjadi percaya } \\
\text { kembali } \\
\text { - memberikan } \\
\text { promosi-promosi } \\
\text { berikan informasi } \\
\text { produk yang } \\
\text { terbaru secara } \\
\text { berkala dengan } \\
\text { gambar yang } \\
\text { menarik } \\
\text { - mengadakan kontes } \\
\text { untuk mendesain } \\
\text { mebel r } \\
\text { - mengamati } \\
\text { komentar dan } \\
\text { feedback dari } \\
\text { pelanggan dan } \\
\text { berikan respon } \\
\text { secepatnya }\end{array}$ & $\begin{array}{l}\text { - Keterlibatan } \\
\text { pelanggan }\end{array}$ & $\begin{array}{l}\text { - Meningkatnya } \\
\text { komentar } \\
\text { positif yang } \\
\text { menjawab } \\
\text { komentar } \\
\text { negatif } \\
\text { pelanggan } \\
\text { - Mengingatnya } \\
\text { traffic ke } \\
\text { website } \\
\text { perusahaan }\end{array}$ \\
\hline 5 & $\begin{array}{l}\text { Responsif } \\
\text { terhadap } \\
\text { permintaa } \\
\text { n terhadap } \\
\text { produk. }\end{array}$ & $\begin{array}{l}\text { Enhance } \\
\text { customer } \\
\text { service } \\
\text { Facilitate } \\
\text { research } \\
\text { and } \\
\text { developme } \\
n t\end{array}$ & $\begin{array}{l}\text { - Meningkatkan } \\
\text { komentar positif } \\
\text { dan mengurangi } \\
\text { komentar } \\
\text { negatif. } \\
\text { Menghasilkan } \\
\text { ide-ide baru } \\
\text { untuk } \\
\text { meningkatkan } \\
\text { kenyamanan } \\
\text { pada produk, } \\
\text { membuat produk } \\
\text { baru, dan melihat } \\
\text { produk yang } \\
\text { sedang diminati } \\
\text { oleh pelanggan. }\end{array}$ & $\begin{array}{l}\text { Business } \\
2.0\end{array}$ & $\begin{array}{l}\text { - Berikan informasi } \\
\text { yang jelas terhadap } \\
\text { cara pemesanan } \\
\text { - Berikan informasi } \\
\text { yang jelas mengenai } \\
\text { cara pembayaran. } \\
\text { - Berikan informasi } \\
\text { untuk pengiriman. } \\
\text { Jika pelanggan } \\
\text { minta barang } \\
\text { dikirimkan biaya } \\
\text { pengiriman harus } \\
\text { disepakati dari awal } \\
\text { akan dibeban ke } \\
\text { pelanggan atau } \\
\text { ditanggung oleh } \\
\text { perusahaan } \\
\text { - Memberikan diskon }\end{array}$ & $\begin{array}{l}\text { - Keterlibatan } \\
\text { pelanggan } \\
\text { - Komitmen } \\
\text { perusahaan } \\
\text { - Jumlah } \\
\text { Transaksi }\end{array}$ & $\begin{array}{l}\text { - Permintaan } \\
\text { terhadap produk } \\
\text { meningkat } \\
\text { - Penjualan } \\
\text { barang } \\
\text { meningkat }\end{array}$ \\
\hline 6 & $\begin{array}{l}\text { Follow-up } \\
\text { pelanggan } \\
\text { setelah } \\
\text { melakukan } \\
\text { pembelian } \\
\text { barang dan } \\
\text { jasa. }\end{array}$ & $\begin{array}{l}\text { Drive } \\
\text { leads and } \\
\text { sales }\end{array}$ & $\begin{array}{l}\text { Meningkatkan } \\
\text { kepuasan } \\
\text { pelanggan } \\
\text { karena } \\
\text { pelanggan } \\
\text { merasa } \\
\text { diperhatikan oleh } \\
\text { perusahaan. } \\
\text { Meningkatkan } \\
\text { kemungkinan } \\
\text { pelanggan } \\
\text { membeli produk } \\
\text { dari perusahaan. }\end{array}$ & $\begin{array}{l}\text { Business } \\
2.0\end{array}$ & $\begin{array}{l}\text { - update media sosial } \\
\text { dengan barang yang } \\
\text { berhasil dikirim dan } \\
\text { tag nama pelanggan } \\
\text { dalam akun media } \\
\text { sosial } \\
\text { barang yang diterima } \\
\text { pelanggan sama } \\
\text { dengan yang dilihat } \\
\text { melalui internet } \\
\text { - jika ada kerusakan } \\
\text { pada barang maka } \\
\text { sediakan jalan } \\
\text { keluar }\end{array}$ & $\begin{array}{l}\text { Kepuasan } \\
\text { pelanggan } \\
\text { - Meningkatnya } \\
\text { jumlah } \\
\text { pelanggan baru } \\
\text { - Score } \\
\text { sentiment } \\
\text { negatif }\end{array}$ & $\begin{array}{l}\text { - Jumlah } \\
\text { pelanggan } \\
\text { meningkat } \\
\text { - Ratio sentiment } \\
\text { positif } \\
\text { meningkat } \\
\text { - Respon positif } \\
\text { pelanggan yang } \\
\text { menerima } \\
\text { barang } \\
\text { meningkat }\end{array}$ \\
\hline
\end{tabular}

